\title{
Chemical, Nutritional and Sensory Analysis of Zobo Drink (Var Sabdariffa) and Selected Soft Drinks
}

\author{
J.C. Osueke and F.N. Ehirim \\ Department of Food Science and Technology, Imo State University, Owerri
}

\begin{abstract}
The zobo drink was prepared from dried zobo calyces, and divided into two batches. One batch was carbonated, and the other batch was non-carbonated. The zobo drink and selected soft drinks were subjected to chemical, nutritional and sensory evaluation. The results showed that zobo was lower in titrable acidity, sodium and phosphorus contents but was higher in protein, ash, total soluble solids and vitamin C contents than the selected soft drinks. Sensory evaluation result showed that consumers rated the carbonated zobo drink higher than the soft drinks and the non-carbonated zobo.
\end{abstract}

\section{INTRODUCTION}

Most non-alcoholic beverages consumed in Nigeria have their roots in foreign countries from where they are shipped in to Nigeria as concentrates. Our major markets are flooded with various brands of soft drinks that are not indigenous to our country. Nigeria is endowed with local beverages not only to cater for her citizen, but surplus enough for export. The rush for these "supposed" superior imported drinks to the neglect of the more nutritious local beverages, in most cases emanates from lack of knowledge of the nutritional value of these local beverages and misconception created through false advertisement of these imported drinks.

Zobo drink (Sorrel, zoborodo) is a local beverage made from the reddish purple, acid-succulent calyces of the flower Hibiscus Sabdariffa. This flower is highly cultivated in the northern part of this country probably because of the climate. There is paucity of information on the nutritional value of zobo drink, as earlier studies were concentrated on the characteristics of the plant and it's seed as well as the evaluation of it's medicinal value (Pursoglove 1981; El-shabrawy et al 1988). This work aims at comparing the nutritional value of zobo drink with selected soft drinks consumed in Owerri metropolis Imo State, Nigeria.

\section{MATERIALS AND METHODS}

Raw Materials: Dried zobo calyces and the other ingredients (sugar, ginger garlic, strawberry flavor) were purchased from Owerri main market Imo State, while two brands of drinks were purchased from a supermarket in Owerri. They were randomly selected and coded Sample A and Sample B respectively.

ZOBO DRINK PRODUCTION: The zobo drink was produced by the traditional method as practiced by many families in Imo State with slight modifications to suit the purpose of this

Journal of the Faculty of Agriculture and Veterinary Medicine, Imo State University, Owerri www.imsu-jafs.com 
study (figure 1). $200 \mathrm{~g}$ of sorted dried zobo calyces (roselle) were boiled in 10 liters of water for 15 minutes. The mixture was allowed to cool to $40^{\circ} \mathrm{C}-50^{\circ} \mathrm{C}$, then strained; $250 \mathrm{~g}$ of sugar, $4 \mathrm{~g}$ of ginger, $1 \mathrm{~g}$ of garlics and $2 \mathrm{ml}$ of strawberry flavor were added and thoroughly mixed. The zobo liquor was filtered with muslin cloth, filled into plastic bottles and pasteurized at $70-78^{\circ} \mathrm{C}$ for 20 minutes after corking. They were cooled and kept for subsequent analysis.

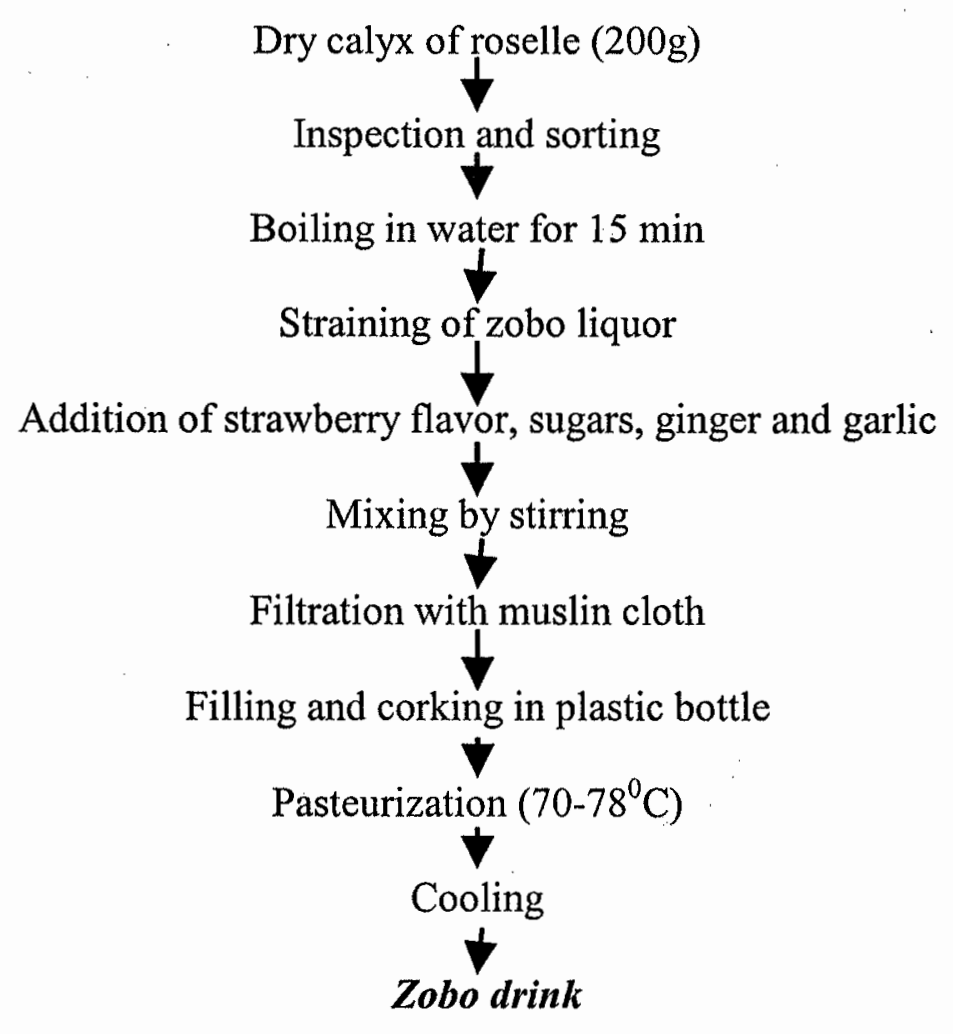

Fig. 1: flow chart for the production of zobo drink

CHEMICAL AND NUTRITIONAL ANALYSIS: The selected soft drinks ands the noncarbonated zobo drink were subjected to chemical and nutritional analysis. The protein was determined using kjeldahl procedure and the minerals (calcium, magnesium, potassium, sodium, and phosphorus) were determined by the method of A.O.A.C. (1990). The ash contents and titrable acidity were evaluated by the method of Pearson (1976). All determinations were carried out in triplicate.

SENSORY EVALUATION: Ten semi-trained panelists carried out subjective evaluation of quality on the drink samples. This composed of the students and staff of the Department of Food Science and Technology, Imo State University, Owerri. Panel members scored for color, flavor, taste and general acceptability using the 9-point hedonic scale (Thekoronye and Ngoddy, 1985). 
STATISTICAL ANALYSIS: All data set were subjected to analysis of variance, while Turkey's test was used to determine significant differences as described by Iwe (2000).

\section{RESULTS AND DISCUSSIONS}

The protein content of zobo was significantly higher than that of the selected soft drinks $(p<0.05)$ (Table 1). The high protein of the zobo drink can be attributed to the natural source of the zobo drink (plant protein). Duke (1985) recorded a $7.9 \%$ protein content of the dried zobo flowers in an earlier study. The low protein content of the soft drinks is not unexpected since their major ingredient is syrup.

\section{Table 1: Nutritional and Chemical of Composition of Zobo Drink and other Soft Drinks (\%)}

\begin{tabular}{lccllllllll}
\hline & Ash & $\mathrm{Na}$ & $\mathrm{Mg}$ & $\mathrm{PK}$ & $\mathrm{Ca}$ & $\mathrm{TTA}$ & $\mathrm{p}^{\mathrm{H}-}$ & $\mathrm{TSS}$ & Protein & Vit.C $\mathrm{mg} / 100 \mathrm{~g}$ \\
\hline Zobo & 0.27 & 0.01 & 0.05 & 0.06 & 0.03 & 0.001 & 6.58 & $6.40^{\mathrm{a}}$ & $2.40^{\mathrm{a}}$ & $9.80^{\mathrm{a}}$ \\
sample A & 0.15 & 0.4 & 0.3 & 00.7 & 0.007 & 0.005 & 4.70 & $5.00^{\mathrm{a}}$ & $0.44^{\mathrm{b}}$ & $2.20^{\mathrm{b}}$ \\
Sample B & 0.13 & 0.01 & 0.10 & 0.50 & 0.001 & 0.005 & 5.80 & $5.30^{\mathrm{a}}$ & $0.40^{\mathrm{a}}$ & $1.00^{\mathrm{b}}$ \\
\hline
\end{tabular}

*Values carrying different superscripts are significant are significantly different $(\mathrm{P}<0.05)$

**Values without superscripts were not subjected to statistical analysis.

The Vitamin $\mathrm{C}$ content of zobo drink was significantly $(\mathrm{p}<0.05)$ higher than that of the other soft drinks while zobo drink had $9.8 \mathrm{mg} / 100 \mathrm{~g}$ vitamin C, Samples A and B had $2.2 \mathrm{mg} / 100 \mathrm{~g}$ and $1.00 \mathrm{~g} / 100 \mathrm{~g}$ of Vitamin $\mathrm{C}$ respectively. The trace amounts of vitamin $\mathrm{C}$ in the selected soft drinks could be as a of result Ascorbic acid while zobo is naturally loaded with vitamin C. Duke (1985) has earlier noted that zobo contains vitamin $\mathrm{C}$ which raises the immune system of the body.

The ash content of zobo drink was fairly higher than the other two samples indicating its high mineral value. Rao-pu (1996) recorded that roselle generally contained high amount of ash, which indicates that the plant provides appreciable quantity of minerals required by the body. The total titrable acidity (TTA) of the selected soft drinks was higher than that of zobo drink. This could partly be as a result of the acid preservatives and also due to carbon dioxide contents of the drinks, which also contributed to the acidity. There was no significant difference in the total soluble solid (TTS) of the drinks $(\mathrm{p}<0.05)$.

The sensory evaluation result (Table 2) revealed that the carbonated zobo was rated higher than the other soft drinks in terms of taste / flavor and general acceptability, except in color where zobo was scored significantly lower $(\mathrm{p}<0.05)$. 
Table 2: Sensory properties of zobo and other Soft Drinks

\begin{tabular}{lccc}
\hline Samples & Flavors $/$ taste & Color & General acceptability \\
\hline Non-carbonated zobo & $5.1^{\mathrm{b}}$ & $5.2^{\mathrm{b}}$ & $\mathrm{s} 6.1^{\mathrm{b}}$ \\
Carbonated zobo & $7.8^{\mathrm{a}}$ & $5.4^{\mathrm{b}}$ & $8.5^{\mathrm{a}}$ \\
Sample A & $5.2^{\mathrm{b}}$ & $8.9^{\mathrm{a}}$ & $6.3^{\mathrm{b}}$ \\
Sample B & $5.6^{\mathrm{b}}$ & $8.7^{\mathrm{a}}$ & $6.3^{\mathrm{b}}$ \\
\hline
\end{tabular}

*Means are from (1) dislike extremely to (9) like extremely

** Values carrying superscript are significantly different $(p<0.05)$

\section{REFERENCES}

A.O.A.C. (1990) Official methods of Food analysis. Association of Official Analytical Chemist (15 $5^{\text {th }}$ edition), Washington D.C.

Duke J.A. (1985). Hand Book of Medical Herbs. $5^{\text {th }}$ edition CRS Press Inc. Bocapution, Florida PP 285-289

El-Shabraw, O., Arbid M., El-Nza H. (1998). Effect of hibiscus sabdariffa on the blood pressure, sperm quality and genital organs of rats. Egyptian J. of vet. Sc. 25:41-47.

Thekoronye A.I. and Ngoddy P.O. (1985). Integrated Food Science and Technology for the Tropics. Macmillan pub. Co. 1td., London. Pp170-190s

Iwe M.O. (2000). Sensory Methods of Food Analysis. Rejoint Communication Pub. Enugu, Nigeria. PP 49-52

Pearson D. (1976). The Chemical Analysis of Food. Churchill Livingstone Pub. New York Pp. 6-10

Pursoglove, T.W.(1981). Tropical Crops (Dicotyledons) Longman Pub. Ltd. Singapore. Pp. 370374

Rao-pu (1996). Nutrient Composition and Biological Evaluation of Mesta (Hibiscus sabdariffa) seeds. Plant Food for Human Nutr. 49: 34-37. 